\title{
NOTE
}

\section{Virus-like particles associated with mortalities of the Manila clam Ruditapes philippinarum in England}

\author{
K. S. Bateman*, P. White, M. Longshaw \\ Centre for Environment, Fisheries and Aquaculture Science (Cefas), Barrack Road, Weymouth, Dorset DT4 8UB, UK
}

\begin{abstract}
Mortalities of the Manila clam Ruditapes philippinarum (Adams \& Reeve, 1850) were reported in southern England (Kent and Poole Harbour) during late spring of 2008. In response to these reported mortalities, samples were collected from 5 sites across the south coast of England. Clams were sampled for both histology and electron microscopy. Transmission electron microscopy (TEM) revealed unenveloped virus-like particles within the connective tissue of the gills and surrounding the tubules in the digestive gland. The virus-like particles appeared to be free within the cytoplasm or associated with endoplasmic reticulum membranes and cytoplasmic vesicles. Particles were icosahedral in shape, with a diameter of 25 to $30 \mathrm{~nm}$. The location, size and morphology of the virus-like particles suggest that they belong to the Picornaviridae family. This is the first report of this virus infection in wild and farmed $R$. philippinarum within the UK.
\end{abstract}

KEY WORDS: Bivalve $\cdot$ Manila clam $\cdot$ Virus

Resale or republication not permitted without written consent of the publisher

\section{INTRODUCTION}

The Manila clam Ruditapes (= Tapes = Venerupis) philippinarum (= semidecussatus) (Adams \& Reeve, 1850 ) is a sediment-dwelling bivalve mollusc belonging to the family Veneridae. The species originates from the Indo-Pacific but was introduced into Europe in 1972 for commercial purposes. The first report of a naturalised population within the UK was in Poole Harbour, Dorset, England (Jensen et al. 2004); the species is now fully established within the harbour and supports a large fishery. In 2006, approximately $386 \mathrm{t}$ of clams were landed in the UK, with an estimated value of 1.5 million pounds sterling; Poole Harbour accounted for the bulk of this catch.

There are several reports of pathogens and parasites in Ruditapes spp., some of which have been associated with mortalities. The first virus reported in clams was described infecting the carpet shell clam
Tapes decussatus by Novoa \& Figueras (2000) who reported that cultured clams in Spain were undergoing abnormal mortalities in 2 culture areas of NW Spain. Whilst several protistan parasites, including Haplosporidium sp. and a coccidian were noted, these were considered by the authors to be of limited significance in the observed mortalities. In samples of the clams undergoing mortalities, the authors consistently observed virus-like particles free within the cytoplasm of connective tissue cells or associated with endoplasmic reticulum membranes. These particles were unenveloped, icosahedral-spherical in shape and measured 27 to $35 \mathrm{~nm}$ in diameter. However, the authors were not able to unequivocally link the presence of these Picornaviridae-like virus particles with the observed mortalities. No histopathological data was provided. Montes et al. (2001) described a viral infection in the cytoplasm and nuclei of gill epithelium, haemocytes, endothelial 
cells, neurons, striated muscle fibres and connective tissues of Manila clams (as T. semidecussatus). Infected gill epithelial cells were hypertrophied with a swelling of the apical regions leading to alterations in ciliary structure. The authors considered that the presence of Perkinsus atlanticus in infected animals predisposed them to an increased risk of infection, as the virus was rarely found in individuals not infected by $P$. atlanticus. Virus particles were approximately $46 \mathrm{~nm}$ in diameter, icosahedral-shaped, homogeneously electron-dense and non-enveloped. A herpes-like virus was reported in $R$. philippinarum larvae in France by Renault et al. (2001a,b). Through a combination of molecular, ultrastructural and experimental transmission trials, it has been shown that the herpes infection in Manila clams is most likely due to oyster herpes virus-1 (OsHV-1) (Arzul et al. 2001a,b). Affected individuals typically died within 2 wk post-exposure and histologically showed evidence of margination of the chromatin in the nuclei (Renault et al. 2001a,b).

In March and April 2008, mass mortalities were reported to be occurring within a managed fishery of Manila clams around Poole Harbour and at the same time within a farmed bed in Kent, UK. Samples were taken from both these sites and the surrounding areas on the south coast of the UK, including Portsmouth Harbour and Southampton Water, where there are exploited populations, to investigate the cause of the mortalities.

\section{MATERIALS AND METHODS}

In response to reported mortalities occurring in stocks of the Manila clam Ruditapes philippinarum, samples were collected by hand from 5 sites across the south coast of the UK in spring 2008 and from Southampton Water in June 2010 (Table 1). Where possible, clams were processed on return to the laboratory. Where this was not possible, clams were refrigerated overnight and sampled the following day. Clams were opened and processed for both histology and electron microscopy.

Small pieces $\left(2 \mathrm{~mm}^{3}\right)$ of gill and digestive gland were removed from all clams and fixed in a solution of $2.5 \%$ glutaraldehyde in $0.1 \mathrm{M}$ sodium cacodylate buffer ( $\mathrm{pH} 7.4$ ) with $1.75 \%$ sodium chloride, for $2 \mathrm{~h}$ at room temperature. Fixed tissue samples were rinsed in $0.1 \mathrm{M}$ sodium cacodylate buffer ( $\mathrm{pH} 7.4$ ) and postfixed for $1 \mathrm{~h}$ in $1 \%$ osmium tetroxide in $0.1 \mathrm{M}$ sodium cacodylate buffer. Specimens were washed in 3 changes of $0.1 \mathrm{M}$ sodium cacodylate buffer before dehydration through a graded acetone series. They were then embedded in Agar 100 epoxy (Agar Scientific, Agar 100 pre-mix kit medium) and polymerised overnight at $60^{\circ} \mathrm{C}$ in an oven. Specimens for further processing were selected on the basis of the results from light microscopy. Semi-thin (1 to $2 \mu \mathrm{m}$ ) sections were stained with Toluidine Blue for viewing with a light microscope to identify suitable target areas. Ultrathin sections (70 to $90 \mathrm{~nm}$ ) of target areas were mounted on uncoated copper grids and stained with $2 \%$ aqueous uranyl acetate and Reynolds' lead citrate (Reynolds 1963). Grids were examined using a JEOL JEM 1210 transmission electron microscope (TEM) and digital images captured using a Gatan Erlangshen ES500W camera and Gatan Digital Micrograph ${ }^{\mathrm{TM}}$ software.

Following sampling for electron microscopy, the remaining body of the clam was fixed in Davidson's seawater fixative. Fixation was allowed to proceed for $24 \mathrm{~h}$ before samples were transferred to $70 \%$ industrial methylated spirit. Fixed samples were processed to wax in a vacuum infiltration processor using standard protocols. Sections were cut at a thickness of 3 to $5 \mu \mathrm{m}$ on a rotary microtome and were mounted onto glass slides before staining with haematoxylin and eosin (H\&E) and Feulgen stains. Stained sections were examined by light microscopy (Nikon Eclipse E800) and digital images were taken using the Lucia ${ }^{\mathrm{TM}}$ Screen Measurement System (Nikon).

\section{RESULTS}

Clams collected in 2008 from all 5 sites in southern England showed similar pathologies using histology. No external signs of disease were noted in the clams. Histological lesions consisting of hypertrophied cells with no nuclear changes were primarily observed in the connective tissues and striated muscle fibres, mainly associated with the areas surrounding the digestive gland. Infiltration of haemocytes was typical in these areas (Fig. 1A,B). Ultrastructurally, virus-like particles were noted within the cytoplasm of affected cells of the digestive gland and gills (Fig. 1C). The virus-like particles appeared to be free within the cytoplasm or associated within cytoplasmic vesicles. Each of the virus-like particles was unenveloped and icosahedral-spherical in shape and measured 25 to $30 \mathrm{~nm}$ in diameter (Fig. 1D).

Other than occasional epitheliocystis being observed in the digestive gland of a few clams with minimal associated pathology, no other pathogens were 

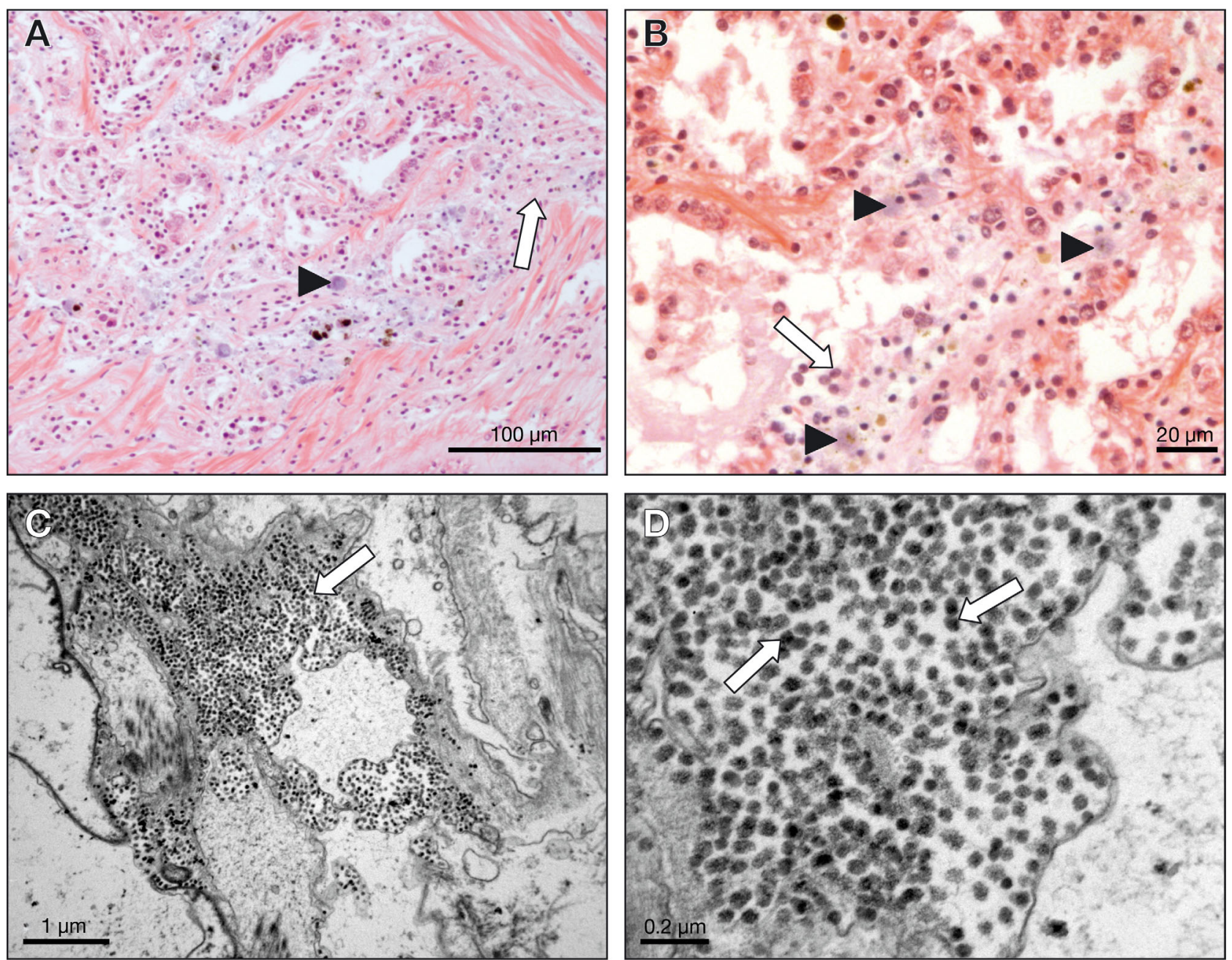

Fig. 1. Ruditapes philippinarum. (A) Low-power photomicrograph through connective tissue of Manila clam undergoing mortality. Affected cells appear to be hypertrophied (black arrowhead). Note haemocyte infiltration associated with infection, in particular near striated muscle (white arrow). H\&E stain. (B) Higher-power view of affected tissues in clams. Affected cells appear to be hypertrophied (black arrowheads), and haemocyte infiltration (white arrow) is apparent. H\&E stain. (C) Multiple virus-like particles (white arrow) within the cytoplasm of infected connective tissue cells within the digestive gland. TEM. (D) Multiple virus-like particles (white arrows). Virions are unenveloped, icosahedral and measure 25 to $30 \mathrm{~nm}$ in diameter. TEM

noted in clams collected in 2008 (Table 1). Clams sampled from Southampton Water in 2010 showed evidence of a viral infection in the connective tissues of 39 individuals out of the 150 sampled. Unlike the clams collected in 2008, other infections were noted in clams from Southampton Water (Table 1). A solitary Rickettsia-like cytoplasmic inclusion (RLO) was observed in the gills of 2 individuals, which was typically delineated from the surrounding tissue by a thin membrane and contained a granular matrix; in addition, Chlamydia-like inclusion bodies (CLOs) were noted in the digestive-gland epithelial cells in 20 animals. The basophilic CLOs occurred in greater numbers compared with the RLO, and up to 20 indi- vidual CLOs were apparent in a single section of the digestive gland. Solitary unidentified digenean metacercariae were noted in 4 individual clams. They occurred within a pearl that was surrounded by a vigorous host response typified by haemocyte infiltration. Four clams showed evidence of small foci of haemocyte aggregations within the connective tissues. No infectious agents were noted in these lesions in 3 out of 4 individuals; in 1 affected clam there were 3 small inclusions in the cytoplasm of a haemocyte measuring approximately 1 to $2 \mu \mathrm{m}$ in diameter and containing a small nucleus. They resembled haplosporidian infections; due to the low numbers present, inclusions were not identified further. 
Table 1. Ruditapes philippinarum. Sampling details and significant pathologies observed at each sampling site. VLP: virus-like particles; RLO: Rickettsia-like cytoplasmic inclusion; CLO: Chlamydia-like inclusion bodies

\begin{tabular}{|c|c|c|c|c|c|c|c|c|}
\hline \multirow[t]{2}{*}{ Site } & \multirow[t]{2}{*}{ Date } & \multirow{2}{*}{$\begin{array}{c}\text { Population } \\
\text { type }\end{array}$} & \multirow{2}{*}{$\begin{array}{c}\text { Clams } \\
\text { sampled (n) }\end{array}$} & \multirow{2}{*}{$\begin{array}{c}\text { Clam } \\
\text { size (mm) }\end{array}$} & \multicolumn{4}{|c|}{ — Pathology prevalence (\%) } \\
\hline & & & & & VLP & RLO & CLO & Digenean \\
\hline Kent & Mar 2008 & Farmed & 30 & 10 & 67 & 0 & 0 & 0 \\
\hline Portsmouth Harbour & Apr 2008 & Wild & 30 & 10 & 93 & 0 & 0 & 0 \\
\hline Poole Harbour Site 1 & Apr 2008 & Wild & 30 & 10 & 47 & 0 & 0 & 0 \\
\hline Poole Harbour Site 2 & Apr 2008 & Wild & 29 & 10 & 83 & 0 & 0 & 0 \\
\hline Southampton Water & Apr 2008 & Wild & 30 & 10 & 87 & 0 & 0 & 0 \\
\hline Southampton Water & Jun 2010 & Wild & 150 & 10 & 26 & 1 & 13 & 3 \\
\hline
\end{tabular}

Overall, prevalence of the pathology consistent with a virus varied markedly between sites. Prevalence of infection in clams from the farmed site in Kent was $67 \%$; in Poole Harbour Site 1, where mortalities had been reported, the prevalence was $47 \%$, whilst prevalence of infection in Poole Harbour Site 2, Southampton Water (2008) and Portsmouth Harbour was 83, 87 and 93\% respectively (Table 1). Sites 1 and 2 in Poole Harbour were approximately 2 miles $(3.2 \mathrm{~km})$ apart.

\section{DISCUSSION}

This is the first report of a picorna-like virus infection in wild and farmed Ruditapes philippinarum within the $\mathrm{UK}_{i}$ the significance of the finding is, however, unknown. Since no other significant pathogens were noted in affected animals, the virus-like particles are implicated in the 2008 mortality event. The repeat sampling of Southampton Water in June 2010 also showed evidence of a viral infection; these clams were also shown to have multiple infections with bacteria and parasites, pathogens not previously seen in clams sampled in 2008. This could be explained by the larger sample size or variation in sampling time (month and year), but may suggest that the stress of the viral infection leaves the clams more susceptible to other opportunistic pathogens.

The size, shape and location of the virus-like particles suggest that they may belong to the Picornaviridae family, and as such are named picorna-like virus particles. However, the assignment of bivalve viruses to viral families based on morphology alone should be regarded as tentative until the biochemical and molecular characteristics of these agents have been defined (Elston 1997). In 1997, heavy mortalities in cultured Ruditapes decussatus were associated with the presence of picorna-like viruses in NW Spain, where the species is also of significant economic importance (Novoa \& Figueras 2000). Further work is needed to establish whether the same virus is associated with both outbreaks, and its relationship to the larger icosahedral virus particle reported in Manila clams by Montes et al. (2001) needs to be considered.

Many different viruses have been described infecting bivalve molluscs, including Herpesviridae, Papovaviridae, Togaviridae, Reoviridae, Birnaviridae and Picornaviridae (Renault \& Novoa 2004). Within Europe, picorna like-viruses have been described in several molluscan groups, and a diverse but unknown community of picorna-like viruses occurs in the ocean (Culley et al. 2003). Rasmussen (1986) reported virus-like particles from marine mussels Mytilus edulis in Denmark; virions were enclosed in vesicles, arranged singly or in paracrystalline arrays and associated with granulocytomas. Granulocytomas have also been reported in $M$. edulis from the UK (Lowe \& Moore 1978) and in Cerastoderma edule from Galicia in NW Spain associated with foci of haemocytic infiltration (Carballal et al. 2003). Unenveloped virus-like particles, measuring 19 to $21 \mathrm{~nm}$ in length with an icosahedral capsid, occurred in paracrystalline arrays in the cytoplasm of $C$. edule.

Mortalities of cultivated seed and adult greenlipped mussels Perna canaliculus in New Zealand were associated with large numbers of unenveloped particles (Jones et al. 1996). Elston (1997) suggested a resemblance of these virus particles with picornaviruses. The absence of mitochondrial inclusions and arrays and the characteristic proliferation of endoplasmic reticulum suggest that the New Zealand virus may be different from that reported in Denmark (Jones et al. 1996). Hine \& Wesney (1997) reported cytological changes in scallops Pecten novaezelandiae and toheroa Paphies ventricosum similar to those reported from Perna canaliculus in New Zealand. Miyazaki et al. (1999) found unenveloped viruses, morphologically similar to picornaviruses, in Japanese pearl oysters Pinctada fucata martensii. However, Miyazaki et al. (1999) noted differences in 
the host cells, area of multiplication and pathological signs between the virus they found and the virus found in Pecten novaezelandiae and Paphies ventricosum by Hine \& Wesney (1997). High mortalities associated with herpes viruses in the abalone Haliotis diversicolor supertexta (Chang et al. 2005), with icosahedral-shaped viruses measuring 50 to $55 \mathrm{~nm}$ in diameter in the epithelial cells of the pen shell Atrina pectinata in Japan (Maeno et al. 2006) and with birnaviruses in Meretrix lusoria from Taiwan (Lo et al. 1988) have been reported.

Viruses generally remain infectious for a relatively short time in natural marine waters (Culley et al. 2003), and several viruses are only detectable in hosts after environmental stressors such as pollution (Renault \& Novoa 2004). In at least one of the sites during the present study (farmed site in Kent), clams were covered for a protracted period of time with a layer of beach sand following a storm event, increasing the stress experienced by these animals. Prevalence of infection by the virus was high in most clam populations examined. The exception was Poole Harbour Site 1, where only $47 \%$ of the clams examined showed histological changes. However, this population was not examined until several weeks after the start of the observed mortality. Thus it is possible that the sample reflects survivors of the mortality event rather than a resistant population. Indeed, the second sample from Poole Harbour was taken at the peak of the mortality event when prevalence was double that originally seen. Although the presence of the virus is associated with mortalities of clams in the present study, demonstration of a causal link is difficult in the absence of controlled experiments. It is likely, however, given the absence of any other visible pathogens, that a combination of environmental stressors coupled with the infection led to the observed mortalities.

Acknowledgements. This work was funded under Defra contracts FA001 and F1166.

\section{LITERATURE CITED}

Arzul I, Renault T, Lipart C, Davison AJ (2001a) Evidence for interspecies transmission of oyster herpesvirus in marine bivalves. J Gen Virol 82:865-870

Arzul I, Renault T, Lipart C (2001b) Experimental herpeslike viral infections in marine bivalves: demonstration of interspecies transmission. Dis Aquat Org 46:1-6
Carballal MJ, Villalba A, Iglesias D (2003) Virus-like particles associated with large foci of heavy hemocytic infiltration in cockles Cerastoderma edule from Galicia (NW Spain). J Invertebr Pathol 84:234-237

Chang PH, Kuo ST, Lai SH, Yang HS, Ting YY, Hsu CL, Chen HC (2005) Herpes-like virus infection causing mortality of cultured abalone Haliotis diversicolor supertexta in Taiwan. Dis Aquat Org 65:23-27

> Culley AI, Lang AS, Suttle CA (2003) High diversity of unknown picorna-like viruses in the sea. Nature 424: 1054-1057

> Elston R (1997) Bivalve mollusc viruses. World J Microbiol Biotechnol 13:393-403

> Hine PM, Wesney B (1997) Virus-like particles associated with cytopathology in the digestive gland epithelium of scallops Pecten novaezelandiae and toheroa Paphies ventricosum. Dis Aquat Org 29:197-204

Jensen AC, Humphreys J, Grisley C, Caldow RWG, Dyrynda P (2004) Naturalisation of the clam Tapes Phillippinarum an alien species and the establishment of a clam fishery within Poole Harbour, Dorset. J Mar Biol Assoc UK 84:1069-1073

Jones JB, Scotti PD, Dearing SC, Wesney B (1996) Virus-like particles associated with marine mussel mortalities in New Zealand. Dis Aquat Org 25:143-149

Lo CF, Hong YW, Huang SY, Wang CH (1988) The characteristics of virus isolated from the gill of clam, Meretrix lusoria. Fish Pathol 23:147-154

Lowe DM, Moore MN (1978) Cytology and quantitative cytochemistry of a proliferative atypical hemocytic condition in Mytilus edulis (Bivalvia, Mollusca). J Natl Cancer Inst 60:1455-1459

Maeno Y, Yurimoto T, Nasu H, Ito S and others (2006) Viruslike particles associated with mass mortalities of the pen shell Atrina pectinata in Japan. Dis Aquat Org 71: 169-173

Miyazaki T, Goto K, Kobayashi T, Kageyama T, Miyata M (1999) Mass mortalities associated with a virus disease in Japanese pearl oysters Pinctada fucata martensii. Dis Aquat Org 37:1-12

- Montes JF, Durfort M, García-Valero J (2001) Parasitism by the protozoan Perkinsus atlanticus favours the development of opportunistic infections. Dis Aquat Org 46:57-66

Novoa B, Figueras A (2000) Virus-like particles associated with mortalities of the carpet-shell clam Ruditapes decussatus. Dis Aquat Org 39:147-149

- Rasmussen LPD (1986) Virus-associated granulocytomas in the marine mussel, Mytilus edulis, from three sites in Denmark. J Invertebr Pathol 48:117-123

> Renault T, Novoa B (2004) Viruses infecting bivalve mollusks. Aquat Living Resour 17:397-409

> Renault T, Lipart C, Arzul I (2001a) A herpes-like virus infecting Crassostrea gigas and Ruditapes philippinarum larvae in France. J Fish Dis 24:369-376

> Renault T, Lipart C, Arzul I (2001b) A herpes-like virus infects a non-ostreid bivalve species: virus replication in Ruditapes philippinarum larvae. Dis Aquat Org 45:1-7

$>$ Reynolds ES (1963) The use of lead citrate at high pH as an electron-opaque stain in electron microscopy. J Cell Biol $17: 208-212$

Submitted: September 5, 2011; Accepted: March 5, 2012

Proofs received from author(s): May 10, 2012
Editorial responsibility: Mike Hine,

Fouras, France 